\title{
The effect of Pandanus amaryllifolius Roxb. extract addition and cooling period on the preference levels, chemical properties and glycemic index of $\mathrm{Cr}$ and $\mathrm{Mg}$ fortified - parboiled rice
}

\author{
${ }^{1, *}$ Yulianto, W.A., ${ }^{1}$ Sulistyani, and ${ }^{2}$ Swasono, F.D.H. \\ ${ }^{1}$ Departement of Food Technology, Faculty of Agro-industry, University of Mercu Buana Yogyakarta, Jl. \\ Wates Km 10, Argomulyo, Bantul, Yogyakarta 55753, Indonesia \\ ${ }^{2}$ Departement of Agrotechnology, Faculty of Agro-industry, University of Mercu Buana Yogyakarta, Jl. \\ Wates Km 10, Argomulyo, Bantul, Yogyakarta 55753, Indonesia
}

\author{
Article history: \\ Received: 7 December 2020 \\ Received in revised form: 27 \\ December 2020 \\ Accepted: 7 June 2021 \\ Available Online: 20 June \\ 2021
}

Keywords:

Cooling,

Fortified parboiled rice,

Glycemic index,

Pandan leaf extract,

Resistant starch

DOI:

https://doi.org/10.26656/fr.2017.5(S2).018

\section{Introduction}

In 2019, Indonesia was the seventh country with the highest incidence of Diabetes Mellitus (DM) in the world, after China, India, USA, Pakistan, Brazil and Mexico (International Diabetes Federation, 2020). A proper diet is one of the best ways to manage the blood sugar levels of patients suffering from DM. Food with a low Glycemic Index $(\mathrm{GI}<55)$ increases the blood sugar level more gradually, therefore, it is a suitable diet for DM patients.

Due to high GI, the consumption of rice which is a staple food in Indonesia is often associated with a high risk of DM (Rohman et al., 2014). However, rice could have a lower GI by undergoing a parboiling process. The glycaemic index values for different rice varieties ranged from 48 to 93 (Boers et al., 2015) and for parboiled rice from 38-87 (Osman et al., 2017). Nisanka and Ekanayake (2016) reported that the GI value of parboiled rice (Nadu Bg 352At) was 40, Bg 360 Samba was 66 and Basmati was 73. A study by Yulianto et al. (2018) showed that the lowest GI (29-30) of parboiled rice could be achieved by adding $\mathrm{Cr}$ fortification and coating it with a cinnamon extract of 6-9\%. Parboiled rice is very beneficial in lowering the blood glucose level of people that are healthy and with type 2 diabetes (Hamad et al., 2017). In the production of parboiled rice, the rice needs to be processed through soaking and boiling or steaming, followed by hulling. Furthermore, soaking and steaming in the parboiling process decreases the pasting viscosities, converts the crystalline form of starch into an amorphous one and decreases the GI (Kale et al., 2017; Nawaz et al., 2018) and the starch digestion of rice significantly (Tian et al., 2018).

The parboiling process does not involve cooling which causes starch retrogradation, a process that enables an increase in Resistant Starch (RS) and leads to a decrease in the GI. Retrograded starch is a type of RS that is categorized as RS3 (Englyst et al., 1992). Furthermore, it is very useful because of its thermal stability during cooking and also melts at $155^{\circ} \mathrm{C}$ (Ma et al., 2018). Furthermore, retrogradation occurs rapidly in amylose fractions, but slowly in amylopectin. Cooling of gelatinized starch is known to cause starch retrogradation and increase RS content. Its molecules contain non-crystalline regions, which undergoes 
degeneration during certain storing conditions and at a particular temperature. The study by Ashwar et al. (2016) showed that rice starch produced with cooling treatment contains higher RS (30.31 - 38.65\%) compared to the ones produced without the treatment (4.42 - 10.94\%). A higher yield of RS $(28.76 \%)$ was observed in branch-discarded starches stored at $4{ }^{\circ} \mathrm{C}$ due to higher retrogradation rates than those stored at 32 and $60^{\circ} \mathrm{C}$ (Babu and Parimalavalli, 2018). Furthermore, the parboiled unhulled rice cooled at $0^{\circ} \mathrm{C}$ for $6 \mathrm{hrs}$ and was fortified with $\mathrm{Cr}, \mathrm{Mg}$ and vitamin $\mathrm{D}$ with different edible coating materials. This resulted in a premix parboiled rice that had a GI of 31-54 and an RS of 3.75-10.56 (Yulianto, Susiati, and Adhini, 2018). However, the rice was less favorable to the panelists because of its husky aroma and stale taste.

To improve the aroma of the rice, pandan extract was added as an aroma enhancer during the soaking and cooking stages of the parboiling process. Pandan leaf extract contains 2-acetyl-1-pyrroline compounds that are common in aromatic rice or fragrant rice. It also contains polyphenol that improves insulin sensitivity and control blood sugar level. Moreover, Suryani et al. (2018) stated that feeding ethyl acetate extract from Pandanus amaryllifolius leaves to diabetic rats reduce blood glucose and malondialdehyde levels in their liver and increase the blood insulin levels. Parboiling the grains slightly increased polyphenol and produced low-medium GI, which could be beneficial for health promotion (Kongkachuichai et al., 2020). Furthermore, Bora et al. (2018) stated that parboiling could be an effective way to produce millet products with higher phenolic acids antioxidant activity. In addition, because diabetic patients have chromium (Anderson, 2008) and magnesium deficiency (Dong et al., 2011) which increases blood sugar levels, it was necessary to increase the $\mathrm{Cr}$ fortification during the boiling process.

The aim of this study is to determine the effect of adding pandan extract, $\mathrm{Cr}$ and $\mathrm{Mg}$ by soaking $\left(65^{\circ} \mathrm{C}\right)$ and cooking $\left(100^{\circ} \mathrm{C}\right)$ paddy, the length of cooling time on the preference level, level of fortificants, and the RS and GI of parboiled rice.

\section{Materials and methods}

\subsection{Materials}

Ciherang rice (medium level of amylose), which has been officially certified as Ciherang paddy seeds, was used in this study and was obtained from an agriculture shop in Sleman, Special Region of Yogyakarta, Indonesia. Pandan leaves (Pandanus amaryllifolius Roxb.) were used as natural herbal aroma enhancers. The source of $\mathrm{Cr}$ and $\mathrm{Mg}$ was from chromium chloride
(Sigma-Aldrich; food grade) and magnesium acetate (Sigma-Aldrich; food grade). Furthermore, other chemicals and reagents were analytical grades (SigmaAldrich). Enzymes for RS analysis are amyloglucosidase solution (Novo Nordisk, Copenhagen), heat-stable $\alpha$ amylase (Termamyl, Novo Nordisk), pullulanase (Novo Nordisk), pancreatin (amylase, Pancrex V Greenford, $\mathrm{UK}$ ), and invertase solution (BDH).

\subsection{Preparation of the pandan extract}

A total of $500 \mathrm{~g}$ of pandan leaves were finely cut into $2 \mathrm{~cm}$ long slivers, pulverized and soaked for extraction in $5 \mathrm{~L}$ of water. The solution was filtered using plain calico, and the $10 \%$ pandan extract was stored in a refrigerator at $4^{\circ} \mathrm{C}$.

\subsection{Production of pandan-extract fortified-parboiled rice}

The chromium and magnesium fortified-parboiled rice was produced using the method that has been applied in previous studies (Yulianto et al., 2015) along with some modifications. The $5 \mathrm{~kg}$ of Ciherang unhulled rice was washed three times with water and finally with aquadest. The good rice (which sank) and the empty hulls (which floated) were separated when washing, before being drained. The use of $10 \%$ pandan extract, $\mathrm{Cr}$ (4 mg chromium chloride/ $\mathrm{L}$ ) and $\mathrm{Mg}$ (9 g magnesium acetate/L) fortificants was conducted as follows: (1) Method 1 - pandan leaf extract and $\mathrm{Cr}$ and $\mathrm{Mg}$ fortificants were added to the soaking mixture at $65^{\circ} \mathrm{C}$ for $2.5 \mathrm{hrs}$; (2) method 2 - $\mathrm{Cr}$ and $\mathrm{Mg}$ was added to the soaking mixture $\left(65^{\circ} \mathrm{C}\right.$ for $\left.2.5 \mathrm{hrs}\right)$, followed by the addition of pandan leaf extract while boiling the rice $\left(100^{\circ} \mathrm{C}\right.$ for $\left.20 \mathrm{mins}\right),(3)$ method 3 - pandan leaf extract and $\mathrm{Cr}$ and $\mathrm{Mg}$ fortificants were added to the soaking mixture $\left(65^{\circ} \mathrm{C}\right.$ for $\left.2.5 \mathrm{hrs}\right)$, followed by the addition of pandan leaf extract (second) while boiling the rice $\left(100^{\circ}\right.$ $\mathrm{C}$ for 20 mins), and (4) method 4 - the rice was soaked in aquadest, followed by the addition of pandan leaf extract and $\mathrm{Cr}$ and $\mathrm{Mg}$ fortificants in the boiling stage $\left(100^{\circ} \mathrm{C}\right.$ for 20 mins).

The rice from each of the methods was drained and cooled at $2{ }^{\circ} \mathrm{C}$ for $0,12,24$ and 36 hrs, and then was dried in a cabinet dryer at $50^{\circ} \mathrm{C}$ until the water content reached $11-12 \%$. The dried rice was then de-hulled to produce parboiled rice which was fortified with chromium, magnesium and pandan extract. Subsequently, the panelists tested the preference level, the level of fortificants, RS, and GI.

\subsection{Preference level test}

This test used the hedonic method on twenty semitrained panelists. Semi-trained panelists refer to people 
who are familiar with the quality of parboiled rice. They were asked to assess different attributes including the quality of taste, aroma, colour, texture, adhesiveness and overall acceptability of the cooked-parboiled rice fortified with chromium, magnesium and pandan extract. The 6-point scale ranged from 1-6, were $1=$ like very much, 2 = like, $3=$ like slightly, $4=$ dislike slightly, $5=$ dislike, $6=$ dislike extremely.

\subsection{Determination of glycemic index}

The determination of the glycemic index was carried out using the methods of Yulianto et al. (2018) which is summarized as follows: A GI test was performed on 16 healthy (non-diabetic) volunteers. Following an overnight fast (10 hrs), each volunteer was asked to consume rice that contained $50 \mathrm{~g}$ glucose from sixteen types derived from each treatment. After two hrs, blood samples were taken every $30 \mathrm{mins}$ to measure the level of glucose (at 30, 60, 90 and 120 mins). Each rice sample was tested by 3 volunteers with a food reference (control) of $50 \mathrm{~g}$ glucose. Blood glucose levels at each sampling time were plotted on two axes, namely the time (X) and blood glucose level (Y) axis. GI was calculated based on the area under the curve of each volunteer's blood sugar level after consuming the rice produced. The curve of the blood sugar level during fasting, within 2 hrs of consuming standard food (glucose) and cooked parboiled rice is illustrated in Figure 1. GI was determined by dividing the area under the curve between GI measured and the reference food (glucose) and multiplying the result by 100 (Wolever et al., 1991; Foster-Powell et al., 2002).

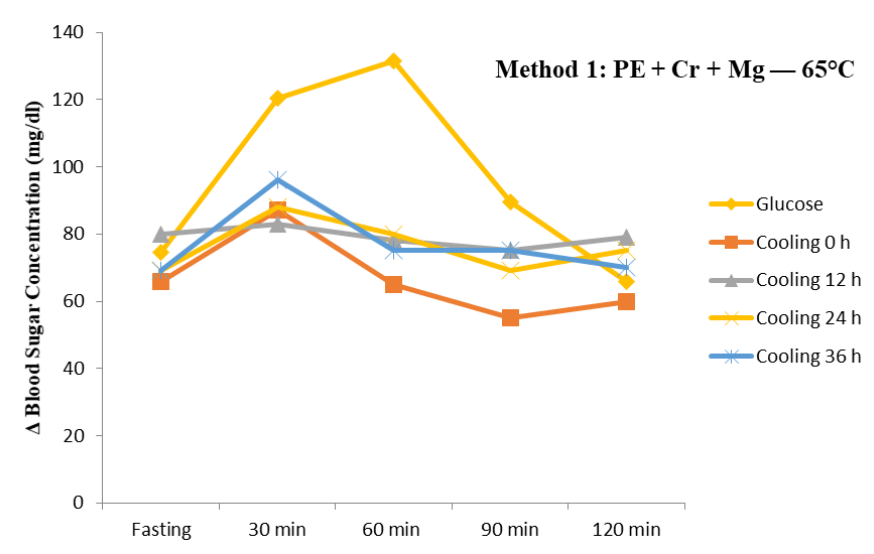

Figure 1. The changes of blood sugar levels of healthy volunteers after consuming standard food (glucose) and after consuming parboiled rice with $\mathrm{Cr}, \mathrm{Mg}$ and pandan extract fortificants produced with method $1\left(\mathrm{PE}+\mathrm{Cr}+\mathrm{Mg}-65^{\circ} \mathrm{C}\right)$ and different cooling durations

\subsection{Product and data analysis}

Rice was analysed to determine its $\mathrm{Cr}$ and $\mathrm{Mg}$ levels using atomic absorption spectroscopy (AOAC, 1995). Its RS content was determined using the enzymatic method
(Englyst et al., 1992). Data was analysed using a completely randomized design with four treatment methods (method 1, 2, 3, 4) and cooling duration $(0,12$, 24 and $36 \mathrm{hrs}$ ). Furthermore, it was analyzed using ANOVA with a $95 \%$ confidence interval. When there was a significant difference in each treatment, the Duncan Multiple Range Test was conducted. The total treatment combination was 16 treatments with 3 replicates.

\section{Results and discussion}

\subsection{Preference levels}

This test was conducted to evaluate the panellists preference levels of parboiled rice fortified with chromium, magnesium and pandan extract. The results contained the assessment of quality attributes, include colour, aroma, texture, flavour, adhesiveness and overall acceptability of the parboiled rice as presented in Table 1. There was an interaction between the method used to add pandan extract and fortificants and the cooling durations that resulted in significant difference between the panelists preference levels for the overall attributes.

The overall score given by the panellists on parboiled rice covered all attributes including colour, aroma, stickiness, taste and texture. Table 1 shows that the fortified parboiled rice was accepted by the panellists between 'like' and like slightly' (2.25-3.20 score). The parboiled rice, which was fortified with chromium and magnesium was soaked in pandan extract in method 3 and cooled for $0 \mathrm{hr}$, was preferred by the panellists with a score of 2.25 . The score was not significantly different from the other treatments. The addition of the pandan extract twice, during the soaking and boiling stages could not increase the preference level, except when cooled for some time. The colour changes in the parboiled rice were caused by migration of the husk and bran pigments, and enzymatic and non-enzymatic browning of the Maillard type (Lamberts et al., 2006). The E-amino group of protein-bound lysine was affected more by parboiling conditions and loss in Maillard reactions, than that of free lysine. The red colour changed to being yellow when parboiling the brown rice (Lamberts et al., 2008). Furthermore, the hardened rice texture was due to starch retrogradation. The longer the soaking time and the higher the amount of chromium added, the harder the rice texture generated (Yulianto et al., 2017). Wariyah et al. (2014) stated that the duration spent on cooking the calcium-fortified rice was very long due to its reduced water-binding capacity. In addition, the cooking quality of rice that is fortified with calcium would decrease. 
Table 1. Preference levels of cooked-parboiled rice fortified with $\mathrm{Cr}, \mathrm{Mg}$ and pandan extract (PE)

\begin{tabular}{|c|c|c|c|c|c|c|c|}
\hline \multirow{2}{*}{$\begin{array}{l}\text { Addition method of pandan extract and } \\
\text { fortificants }\end{array}$} & \multirow{2}{*}{$\begin{array}{c}\text { Cooling } \\
\text { duration (hrs) }\end{array}$} & \multicolumn{6}{|c|}{ Parameter } \\
\hline & & Color & Aroma & Stickiness & Texture & Taste & Overall \\
\hline \multirow{4}{*}{$\mathrm{PE}+\mathrm{Cr}+\mathrm{Mg}-65^{\circ} \mathrm{C}$} & 0 & $2.80^{\mathrm{bcd}}$ & $2.20^{\mathrm{ab}}$ & 3 & $3.30^{\mathrm{ab}}$ & $2.90^{\mathrm{ab}}$ & $2.90^{\mathrm{bc}}$ \\
\hline & 12 & $2.40^{\mathrm{abc}}$ & $2.40^{\mathrm{abc}}$ & 2.7 & $2.75^{\mathrm{a}}$ & $2.65^{\mathrm{ab}}$ & $2.60^{\mathrm{abc}}$ \\
\hline & 24 & $2.35^{\mathrm{ab}}$ & $2.50^{\mathrm{abcd}}$ & 2.95 & $3.15^{\mathrm{ab}}$ & $2.85^{\mathrm{ab}}$ & $2.80^{\mathrm{abc}}$ \\
\hline & 36 & $3.00^{\text {cde }}$ & $2.70^{\mathrm{bcd}}$ & 3.1 & $3.45^{\mathrm{b}}$ & $2.65^{\mathrm{ab}}$ & $2.70^{\mathrm{abc}}$ \\
\hline \multirow{4}{*}{$\mathrm{Cr}+\mathrm{Mg}-65^{\circ} \mathrm{C}$ and $\mathrm{PE}-100^{\circ} \mathrm{C}$} & 0 & $2.70^{\mathrm{bcd}}$ & $2.00^{\mathrm{a}}$ & 2.8 & $3.00^{\mathrm{ab}}$ & $2.45^{\mathrm{ab}}$ & $2.65^{\mathrm{abc}}$ \\
\hline & 12 & $2.40^{\mathrm{abc}}$ & $2.35^{\mathrm{abc}}$ & 2.7 & $3.05^{\mathrm{ab}}$ & $2.80^{\mathrm{ab}}$ & $2.60^{\mathrm{abc}}$ \\
\hline & 24 & $2.55^{\mathrm{bcd}}$ & $2.75^{\mathrm{bcd}}$ & 2.95 & $2.85^{\mathrm{ab}}$ & $2.45^{\mathrm{ab}}$ & $2.85^{\mathrm{bc}}$ \\
\hline & 36 & $2.90^{\mathrm{bcd}}$ & $2.70^{\mathrm{bcd}}$ & 3.1 & $3.15^{\mathrm{ab}}$ & $2.75^{\mathrm{ab}}$ & $3.10^{\mathrm{c}}$ \\
\hline \multirow{4}{*}{$\mathrm{PE}+\mathrm{Cr}+\mathrm{Mg}-65^{\circ} \mathrm{C}$ and $\mathrm{PE}-100^{\circ} \mathrm{C}$} & 0 & $1.85^{\mathrm{a}}$ & $2.20^{\mathrm{ab}}$ & 2.65 & $2.70^{\mathrm{a}}$ & $2.55^{\mathrm{ab}}$ & $2.25^{\mathrm{a}}$ \\
\hline & 12 & $2.70^{\mathrm{bcd}}$ & $2.80^{\mathrm{bcd}}$ & 3.1 & $3.20^{\mathrm{ab}}$ & $2.95^{\mathrm{b}}$ & $2.90^{\mathrm{bc}}$ \\
\hline & 24 & $2.80^{\mathrm{bcd}}$ & $2.80^{\mathrm{bcd}}$ & 2.85 & $3.05^{\mathrm{ab}}$ & $2.65^{\mathrm{ab}}$ & $2.95^{\mathrm{bc}}$ \\
\hline & 36 & $3.15^{\mathrm{de}}$ & $2.90^{\text {cd }}$ & 2.9 & $2.85^{\mathrm{ab}}$ & $3.00^{\mathrm{b}}$ & $3.20^{\mathrm{c}}$ \\
\hline \multirow{4}{*}{$\mathrm{PE}+\mathrm{Cr}+\mathrm{Mg}-100^{\circ} \mathrm{C}$} & 0 & $1.85^{\mathrm{a}}$ & $2.40^{\mathrm{abc}}$ & 2.75 & $2.75^{\mathrm{a}}$ & $2.30^{\mathrm{a}}$ & $2.40^{\mathrm{ab}}$ \\
\hline & 12 & $2.40^{\mathrm{abc}}$ & $2.40^{\mathrm{abc}}$ & 2.65 & $2.75^{\mathrm{a}}$ & $2.40^{\mathrm{ab}}$ & $2.45^{\mathrm{ab}}$ \\
\hline & 24 & $2.50^{\mathrm{bc}}$ & $2.60^{\mathrm{abcd}}$ & 2.85 & $2.75^{\mathrm{a}}$ & $2.45^{\mathrm{ab}}$ & $2.65^{\mathrm{abc}}$ \\
\hline & 36 & $3.45^{\mathrm{e}}$ & $3.15^{\mathrm{d}}$ & 2.85 & $2.80^{\mathrm{ab}}$ & $2.90^{\mathrm{ab}}$ & $3.10^{\mathrm{c}}$ \\
\hline
\end{tabular}

Values with the same superscript in the same column are not significantly different $(\mathrm{P}<0.05)$.

\subsection{Fortificants (Cr and $\mathrm{Mg}$ )}

In general, the concentrations of $\mathrm{Mg}$ and $\mathrm{Cr}$ fortification are constant or do not change under method 2,3 , and 4 during cooling. In method 1 , (soaking) the longer the cooling time, the more the $\mathrm{Cr}$ and $\mathrm{Mg}$ levels tend to decrease. The statistical analysis results showed that soaking unhulled (whole) rice in pandan extract and varying the cooling periods affected the chromium levels in parboiled rice by $0.03-0.07 \mathrm{mg} / \mathrm{kg}$ (Table 2). Premix rice that was made from the different types and concentrations of fortificants resulted in the highest chromium level of $0.26 \mathrm{mg} / \mathrm{kg}$ (Yulianto, Susiati, and Adhini, 2018). The low chromium level (0.03-0.07 mg/ $\mathrm{kg}$ ) of parboiled rice was due to the absorption of chromium by the husk and bran. This was in line with other research (Prom-u-thai et al., 2010) on $\mathrm{Zn}$ fortification which showed that most $\mathrm{Zn}$ diffused into the bran during soaking with only a scant amount being absorbed by the grain. This occurred because bran is rich in substances that absorb $\mathrm{Zn}$, such as phytate and protein.
Therefore, it impedes $\mathrm{Zn}$ mobility into the endosperm. Magnesium levels in parboiled rice were 56.50 to 144.70 $\mathrm{mg} / \mathrm{kg}$. The lowest and the highest levels of magnesium were yielded from method 1 and method 4, respectively, with a $36 \mathrm{hrs}$ cooling period. The magnesium level of premix rice with different types and concentrations of fortificant was 1113.96 to $1436.47 \mathrm{mg} / \mathrm{kg}$ (Yulianto, Susiati, and Adhini, 2018). Therefore, the fortified parboiled rice contained a relatively low level of magnesium because most of it penetrated the bran during soaking. Furthermore, only a small amount was absorbed by the grains, due to direct bonds with the compounds in rice, such as phytates and proteins.

\subsection{Resistant starch content}

The result of RS analysis in the parboiled rice fortified with chromium, magnesium and pandan extract was presented in Table 3. It was revealed that the treatment in method 1 with a longer cooling time had the tendency to decrease the RS content of parboiled rice. Furthermore, the other methods with longer cooling time

Table 2. The levels of chromium and magnesium of parboiled rice fortified with $\mathrm{Cr}, \mathrm{Mg}$ and pandan extract (PE)

\begin{tabular}{|c|c|c|c|c|c|c|c|c|}
\hline \multirow{3}{*}{$\begin{array}{l}\text { Addition method of pandan extract and } \\
\text { fortificants }\end{array}$} & \multicolumn{8}{|c|}{ Cooling duration } \\
\hline & \multicolumn{2}{|c|}{0 hour } & \multicolumn{2}{|c|}{$12 \mathrm{hrs}$} & \multicolumn{2}{|c|}{$24 \mathrm{hrs}$} & \multicolumn{2}{|c|}{$36 \mathrm{hrs}$} \\
\hline & $\begin{array}{c}\mathrm{Cr} \\
(\mathrm{mg} / \mathrm{kg})\end{array}$ & $\begin{array}{c}\mathrm{Mg} \\
(\mathrm{mg} / \mathrm{kg})\end{array}$ & $\begin{array}{c}\mathrm{Cr} \\
(\mathrm{mg} / \mathrm{kg})\end{array}$ & $\begin{array}{c}\mathrm{Mg} \\
(\mathrm{mg} / \mathrm{kg})\end{array}$ & $\begin{array}{c}\mathrm{Cr} \\
(\mathrm{mg} / \mathrm{kg})\end{array}$ & $\begin{array}{c}\mathrm{Mg} \\
(\mathrm{mg} / \mathrm{kg})\end{array}$ & $\begin{array}{c}\mathrm{Cr} \\
(\mathrm{mg} / \mathrm{kg})\end{array}$ & $\begin{array}{c}\mathrm{Mg} \\
(\mathrm{mg} / \mathrm{kg})\end{array}$ \\
\hline $\mathrm{PE}+\mathrm{Cr}+\mathrm{Mg}-65^{\circ} \mathrm{C}$ & $0.07^{\mathrm{e}}$ & $143.30^{1}$ & $0.06^{\mathrm{d}}$ & $131.80^{\mathrm{j}}$ & $0.04^{\mathrm{b}}$ & $144.70^{\mathrm{m}}$ & $0.04^{\mathrm{b}}$ & $56.50^{\mathrm{a}}$ \\
\hline $\mathrm{Cr}+\mathrm{Mg}-65^{\circ} \mathrm{C}$ and $\mathrm{PE}-100^{\circ} \mathrm{C}$ & $0.05^{\mathrm{c}}$ & $70.00^{\mathrm{c}}$ & $0.04^{\mathrm{b}}$ & $68.60^{\mathrm{b}}$ & $0.04^{\mathrm{b}}$ & $103.90^{\mathrm{e}}$ & $0.04^{\mathrm{b}}$ & $108.80^{\mathrm{f}}$ \\
\hline $\mathrm{PE}+\mathrm{Cr}+\mathrm{Mg}-65^{\circ} \mathrm{C}$ and $\mathrm{PE}-100^{\circ} \mathrm{C}$ & $0.04^{\mathrm{b}}$ & $110.20^{\mathrm{g}}$ & $0.03^{\mathrm{a}}$ & $71.20^{\mathrm{d}}$ & $0.04^{\mathrm{b}}$ & $142.20^{\mathrm{k}}$ & $0.04^{\mathrm{b}}$ & $143.30^{1}$ \\
\hline $\mathrm{PE}+\mathrm{Cr}+\mathrm{Mg}-100^{\circ} \mathrm{C}$ & $0.04^{\mathrm{b}}$ & $122.10^{\mathrm{i}}$ & $0.04^{\mathrm{b}}$ & $112.30^{\mathrm{h}}$ & $0.04^{\mathrm{b}}$ & $110.60^{\mathrm{g}}$ & $0.04^{\mathrm{b}}$ & $122.40^{\mathrm{h}}$ \\
\hline
\end{tabular}

Values are expressed as means of triplicates. Values with the same superscript in the same row and column are not significantly different $(\mathrm{P}<0.05)$. 
Table 3. Resistant starch (\% db) of parboiled rice fortified with $\mathrm{Cr}, \mathrm{Mg}$ and pandan extract (PE)

\begin{tabular}{lcccc}
\hline \multirow{2}{*}{$\begin{array}{c}\text { Addition method of pandan extract and } \\
\text { fortificants }\end{array}$} & \multicolumn{4}{c}{ Cooling duration } \\
\cline { 2 - 5 } & 0 hour & $12 \mathrm{hrs}$ & $24 \mathrm{hrs}$ & $36 \mathrm{hrs}$ \\
\hline $\mathrm{PE}+\mathrm{Cr}+\mathrm{Mg}-65^{\circ} \mathrm{C}$ & $23.62 \pm 0.21^{\mathrm{n}}$ & $23.99 \pm 0.20^{\circ}$ & $22.20 \pm 0.19^{\mathrm{k}}$ & $22.01 \pm 0.20^{\mathrm{j}}$ \\
$\mathrm{Cr}+\mathrm{Mg}-65^{\circ} \mathrm{C}$ and $\mathrm{PE}-100^{\circ} \mathrm{C}$ & $17.96 \pm 0.15^{\mathrm{b}}$ & $21.83 \pm 0.19^{\mathrm{i}}$ & $21.69 \pm 0.18^{\mathrm{h}}$ & $22.35 \pm 0.20^{1}$ \\
$\mathrm{PE}+\mathrm{Cr}+\mathrm{Mg}-65^{\circ} \mathrm{C}$ and $\mathrm{PE}-100^{\circ} \mathrm{C}$ & $13.80 \pm 0.11^{\mathrm{a}}$ & $18.93 \pm 0.16^{\mathrm{c}}$ & $22.19 \pm 0.20^{\mathrm{k}}$ & $21.52 \pm 0.19^{\mathrm{g}}$ \\
$\mathrm{PE}+\mathrm{Cr}+\mathrm{Mg}-100^{\circ} \mathrm{C}$ & $19.18 \pm 0.18^{\mathrm{d}}$ & $21.29 \pm 0.19^{\mathrm{e}}$ & $21.37 \pm 0.19^{\mathrm{f}}$ & $22.54 \pm 0.20^{\mathrm{m}}$ \\
\hline
\end{tabular}

Values are expressed as means of triplicates. Values with the same superscript in the same row and column are not significantly different $(\mathrm{P}<0.05)$.

tend to increase the RS content of parboiled rice. The RS level of the fortified parboiled rice ranged from $13.80 \%$ to $23.99 \%$. The lowest RS $(13.80 \%)$ was obtained from method 3 with no cooling duration, while the highest RS (23.99\%) was from method 1 with 24 hrs cooling duration. This indicates that the method of adding pandan extract and the cooling duration affected the RS level of parboiled rice. Hidayat et al. (2018) stated that cooling at $4^{\circ} \mathrm{C}$ for $60 \mathrm{hrs}$ would increase the resistant starch content $(6.27 \%$ to $15.38 \%)$ of corn-based rice analogues. The controlled cooling of parboiled paddy displayed a higher crystallinity, and starch reorganization (Purohit and Rao, 2017).

Water hydration and partial gelatinization occurred when soaking at $65^{\circ} \mathrm{C}$ for 150 mins, while gelatinization occurred when boiling at $100^{\circ} \mathrm{C}$ for 20 mins. Gelatinization is the disruption of the molecular structure of starch granules during thermal processing (soaking of rough rice) in the presence of water. With the presence of cooling treatment, the degraded molecules with suitable molecular mass are able to re-associate and form tightly packed aggregations. Furthermore, they are stabilized by hydrogen bond, which leads to the formation of RS3 (Ma et al., 2018). The storage of starch gels at $4^{\circ} \mathrm{C}$ induce faster crystallization of amylopectin than at $30^{\circ} \mathrm{C}$ (Zhou et al., 2010). Subsequent cooling and storage lead to retrogradation, in which starch regains an ordered structure that is more resistant to enzymatic digestion. Furthermore, the digestion rate is reduced as the melting enthalpy is increased. The amount of slowly digestible starch and RS, correlated positively with the relative melting enthalpy of the partially gelatinized or retrograded starch samples (Chung et al., 2006). Table 3 shows that cooling for $36 \mathrm{hrs}$ tends to increase the level of RS in the treatment of method 2 dan 4 , but to decrease in the method 1. Starch retrogradation is affected by many factors, such as water content, storage temperature and time, and additives in the system. Babu and Parimalavalli (2018) stated that a combination of autoclaving, debranching and subsequent storage at $4^{\circ} \mathrm{C}$ is the best technique for producing a higher amount of resistant starch in sweet potato.

\subsection{Glycemic index}

Figure 1 describes that the blood sugar level on the consumption of standard solution (glucose) was higher than that of parboiled rice in all treatments. Statistical analysis showed that the method of adding pandan extract and the cooling duration significantly affected the GI (Table 4). The decrease in the blood sugar level, occurred when consuming parboiled rice fortified with chromium and magnesium. This was due to the physiological effect of RS on blood glucose levels. RS is starch that cannot be hydrolyzed by digestive enzymes because it affects the density of the intestinal content which leads to a decrease in $\alpha$-amylose activity. In addition, it obstructs glucose release and absorption.

Table 4 shows that parboiled rice fortified with $\mathrm{Cr}$ and $\mathrm{Mg}$ with the highest GI (47.80) occurred in method 3. While the lowest GI (20.03) occurred in method 1 with a duration of $12 \mathrm{hrs}$. Throughout the parboiling process, partial gelatinization of starch was achieved during soaking, while complete gelatinization was achieved after steaming. Furthermore, the soaking step absorbed the moisture to swallow the starch granules, while the steaming step ruptured the crystalline polyhedral structure was ruptured to yield compact, amorphous and translucent rice. Both soaking and

Table 4. Glycemic index of parboiled rice fortified with $\mathrm{Cr}, \mathrm{Mg}$ and pandan extract (PE)

\begin{tabular}{lcccc}
\hline \multirow{2}{*}{$\begin{array}{c}\text { Addition method of pandan extract and } \\
\text { fortificants }\end{array}$} & 0 hour & $12 \mathrm{hrs}$ & $24 \mathrm{hrs}$ & $36 \mathrm{hrs}$ \\
\cline { 2 - 5 } $\mathrm{PE}+\mathrm{Cr}+\mathrm{Mg}-65^{\circ} \mathrm{C}$ & $29.42 \pm 0.22^{\mathrm{f}}$ & $20.03 \pm 0.19^{\mathrm{a}}$ & $27.16 \pm 0.23^{\mathrm{d}}$ & $23.96 \pm 0.22^{\mathrm{c}}$ \\
$\mathrm{Cr}+\mathrm{Mg}-65^{\circ} \mathrm{C}$ and $\mathrm{PE}-100^{\circ} \mathrm{C}$ & $36.27 \pm 0.34^{\mathrm{k}}$ & $29.44 \pm 0.25^{\mathrm{f}}$ & $31.72 \pm 0.27^{\mathrm{h}}$ & $36.41 \pm 0.31^{1}$ \\
$\mathrm{PE}+\mathrm{Cr}+\mathrm{Mg}-65^{\circ} \mathrm{C}$ and $\mathrm{PE}-100^{\circ} \mathrm{C}$ & $47.80 \pm 0.40^{\mathrm{n}}$ & $21.39 \pm 0.19^{\mathrm{b}}$ & $31.71 \pm 0.28^{\mathrm{h}}$ & $31.26 \pm 0.29^{\mathrm{g}}$ \\
$\mathrm{PE}+\mathrm{Cr}+\mathrm{Mg}-100^{\circ} \mathrm{C}$ & $37.24 \pm 0.33^{\mathrm{m}}$ & $27.31 \pm 0.23^{\mathrm{e}}$ & $32.04 \pm 0.30^{\mathrm{i}}$ & $33.20 \pm 0.33^{\mathrm{j}}$ \\
\hline
\end{tabular}

Values are expressed as means of triplicates. Values with the same superscript in the same row and column are not significantly different $(\mathrm{P}<0.05)$. 
steaming converted the crystalline form of starch into an amorphous one, imparted translucency to the grains, and decreased the GI (Kale et al., 2017). Rice parboiling and cooking increase the RS content due to the alteration of the physico-chemical characteristics (Kale et al., 2015). Parboiling can lower the GI of rice but changing the cooking methods would not cause any significant effect (Darandakumbura et al., 2013).

This study showed that in addition to high levels of retrograded starch, the GI was lowered due to the polyphenol content in the pandan extract. In addition, Kongkachuichai et al. (2020) and Bora et al. (2018) stated that parboiling the grains slightly increased the polyphenol content of rice and millets respectively, and lowered GI.

\section{Conclusion}

The method of adding pandan leaf extract and cooling periods of unhulled rice affected the panelists levels of preference, the level of fortificants, RS, and GI of fortified, parboiled rice. The preference level of the panelists was generally on the scale between 'like' and 'like slightly'. The fortified-parboiled rice contained high to very high RS which is about $13.80 \%-23.99 \% \mathrm{db}$ and GI of $20.03-47.80(<55)$. The lowest GI (20.03) and the highest RS content $(23.99 \%)$ were obtained in method 1 (pandan leaf extract and fortificants added during soaking at $65^{\circ} \mathrm{C}$ for $2.5 \mathrm{hrs}$ ) with cooling during at $2^{\circ} \mathrm{C}$ for $12 \mathrm{hrs}$. Furthermore, the rice preferred by the panelists from method 1 (score of 2.60) contained 0.06 $\mathrm{mg} / \mathrm{kg}$ total $\mathrm{Cr}$ and $131.80 \mathrm{mg} / \mathrm{kg}$ total $\mathrm{Mg}$. Method 1 can be used to produce parboiled rice fortified with $\mathrm{Cr}$ and $\mathrm{Mg}$ which is suitable for diabetics.

\section{Conflict of interest}

The authors declare no conflict of interest.

\section{Acknowledgments}

The author is grateful to the Directorate General of Higher Education, Ministry of Research, Technology and Higher Education, Indonesia for funding this research through the Excellent Applied Program of Higher Education in 2017-2018.

\section{References}

Anderson, R.A. (2008). Chromium and polyphenols from cinnamon improve insulin sensitivity. Proceedings of the Nutrition Society, 67(1), 48-53. https://doi.org/10.1017/S0029665108006010

AOAC. (1995). The Official Methods of Analysis of AOAC International. AOAC International.
Washington, DC: Association of Official Analytical Chemists.

Ashwar, B.A., Gani, A., Wani, I.A., Shah, A., Masoodi, F.A. and Saxena, D.C. (2016). Production of resistant starch from rice by dual autoclavingretrogradation treatment: Invitro digestibility, thermal and structural characterization. Food Hydrocolloids, 56, 108-117. https://doi.org/10.1016/ j.foodhyd.2015.12.004

Babu, A.S. and Parimalavalli, R. (2018). Effect of pullulanase debranching and storage temperatures on structural characteristics and digestibility of sweet potato starch. Journal of the Saudi Society of Agricultural Sciences, 17(2), 208-216. https:// doi.org/10.1016/j.jssas.2016.04.005

Boers, H.M., ten Hoorn, J.S. and Mela, D.J. (2015). A systematic review of the influence of rice characteristics and processing methods on postprandial glycaemic and insulinaemic responses. British Journal of Nutrition, 114(7), 1035-1045. https://doi.org/10.1017/S0007114515001841

Bora, P., Ragaee, S. and Marcone, M. (2018). Effect of Parboiling on Decortication Yield of Millet Grains and Phenolic acids and in vitro Digestibility of Selected Millet Products. Food Chemistry, 274, 718725. https://doi.org/10.1016/j.foodchem.2018.09.010

Chung, H.J., Lim, H.S. and Lim, S.T. (2006). Effect of partial gelatinization and retrogradation on the enzymatic digestion of waxy rice starch. Journal of Cereal Science, 43(3), 353-359. https:// doi.org/10.1016/j.jcs.2005.12.001

Darandakumbura, H.D.K., Wijesinghe, D.G.N.G. and Prasantha, B.D.R. (2013). Effect of processing conditions and cooking methods on resistant starch, dietary fiber and glycemic index of rice. Tropical Agricultural Research, 24(2), 163-174.

Dong, J.Y., Xun, P., He, K. and Qin, L.Q. (2011). Magnesium intake and risk of type 2 diabetes: metaanalysis of prospective cohort studies. Diabetes Care, 34(9), 2116-2122. https://doi.org/10.2337/ dc11-0518

Englyst, H.N., Kingman, S.M. and Cummings, J.H. (1992). Classification and measurement of nutritionally important starch fractions. European Journal of Clinical Nutrition, 46 (Suppl. 2), S33S50.

Foster-Powell, K., Holt, S.H.A. and Brand-Miller, J.C. (2002). International table of glycemic index and glycemic load values: 2002. American Journal of Clinical Nutrition, 76(1), 5-56. https:// doi.org/10.1093/ajen/76.1.5

Hamad, S., Zafar, T.A. and Sidhu, J. (2017). Parboiled 
Rice Metabolism Differs in Healthy and Diabetic Individuals with Similar Improvement in Glycemic Response. Nutrition, 47, 43-49. https:// doi.org/10.1016/j.nut.2017.09.010

Hidayat, B., Muslihudin, M. and Akmal, S. (2018). Application of autoclaving-cooling cycling treatment to improve resistant starch content of corn-based rice analogues. Journal of Physics: Conference Series, 953, 012010. https://doi.org/10.1088/17426596/953/1/012010

International Diabetes Federation (IDF). (2020). Diabetes Atlas 9th edition 2019. Retrieved on April 11, 2020 from IDF Diabetes Atlas Website: www.diabetesatlas.org/upload/resources/2019/ IDF_Atlas_9th_Edition_2019.pdf.

Kale, S.J., Jha, S.K., Jha, G.K., Sinha, J.P. and Lal, S.B. (2015). Soaking induced changes in chemical composition, glycemic index and starch characteristics of basmati rice. Rice Science, 22(5), 227-236. https://doi.org/10.1016/j.rsci.2015.09.002

Kale, S.J., Kale, P.N. and Jha, S.K. (2017). Effects of parboiling steps on starch characteristics and glycemic index of basmati (Pb1121) rice. International Journal of Agriculture Sciences, 9(49), 4826-4831.

Kongkachuichai, R., Charoensiri, R., Meekhruerod, A. and Kettawan, A. (2020). Effect of processing conditions on bioactive compounds and glycemic index of the selected landrace rice variety in prediabetes. Journal of Cereal Science, 94, 102994. https://doi.org/10.1016/j.jcs.2020.102994.

Lamberts, L., Bie, E.D., Derycke, V., Veraverbeke, W.S., De Man, W. and Delcour, J.A. (2006). Effect of processing conditions on color change of brown and milled parboiled rice. Cereal Chemistry Journal, 83(1), 80-85. https://doi.org/10.1094/CC-83-0080

Lamberts, L., Rombouts, I., Brijs, K., Gebruers, K. and Delcour, J.A. (2008). Impact of parboiling conditions on Maillard precursors and indicators in long-grain rice cultivars. Food Chemistry, 110(4), 916-922. https://doi.org/10.1016/ j.foodchem.2008.02.080

Ma, Z., Hu, X. and Boye, J.I. (2018). Research advances on the formation mechanism of resistant starch type III: A review. Critical Reviews in Food Science and Nutrition, 60(2), 276-297. https:// doi.org/10.1080/10408398.2018.1523785

Nawaz, M.A., Fukai, S., Prakash, S. and Bhandari, B. (2018). Effect of soaking medium on the physicochemical properties of parboiled glutinous rice of selected Laotian cultivars. International Journal of Food Properties, 21(1), 1896-1910. https://doi.org/10.1080/10942912.2018.1503301

Nisanka, T.U.S. and Ekanayake, S. (2016). Rice variety and processing: contribution to glycaemic response. Ceylon Medical Journal, 61(4), 159-162. https:// doi.org/10.4038/cmj.v61i4.8381

Osman, N.M.H., Barakatun-Nisak Mohd-Yusof, B. and Ismail, A. (2017). Estimating Glycemic Index of Rice-Based Mixed Meals by Using Predicted and Adjusted Formulae. Rice Science, 24(5), 274-282. https://doi.org/10.1016/j.rsci.2017.06.001

Prom-u-thai, C., Rerkasem, B., Cakmak, I. and Huang, L. (2010). Zinc fortification of whole rice grain through parboiling process. Food Chemistry, 120(3), 858-863.

https://doi.org/10.1016/

j.foodchem.2009.11.027

Purohit, S.R. and Rao, P.S. (2017). Optimization of paddy parboiling process for higher starch crystallinity by response surface methodology. International Journal of Biological Macromolecules 104 (Part A), 1091-1098. https://doi.org/10.1016/ j.ijbiomac.2017.06.089

Rohman, A., Helmiyati, S., Hapsari, M. and Setyaningrum. D.L. (2014). Rice in health and nutrition. International Food Research Journal, 21 (1), 13-24.

Suryani, C. L., Tamaroh, S. and Budipitojo, T. (2018). Increased of hypoglycemic effect and pancreatic regeneration of Pandanus amaryfollius leaves ethyl acetate extract in streptozotocin-induced diabetic rats. International Food Research Journal, 25(5), 1792-1798.

Tian, J., Cai, Y., Qin, W., Matsushita, Y., Ye, X. and Ogawa, Y. (2018). Parboiling reduced the crystallinity and in vitro digestibility of non-waxy short grain rice. Food Chemistry, 257, 23-28. https:// doi.org/10.1016/j.foodchem.2018.03.005

Wariyah, Ch., Anwar,C., Astuti, M. and Supriyadi. (2014). Pasting properties of calcium-fortified rice. International Food Research Journal, 21(3), 10251029.

Wolever, T.M., Jenkins, D.J., Jenkins, A.L. and Josse, R.G. (1991). The glycemic index: methodology and clinical implications. The American Journal of Clinical Nutrition, 54(5), 846-854. https:// doi.org/10.1093/ajen/54.5.846

Yulianto, W.A, Suryani, C.L., Susiati, A.M. and Luwihana, S. (2018). Evaluation of chromium fortified- parboiled rice coated with herbal extracts: resistant starch and glycemic index. International Food Research Journal, 25(6), 2608-2613.

Yulianto, W.A., Slamet, A., Luwihana, S. and Suprayogi, S.A.D. (2015). Evaluation of Chromium 
Fortified Parboiled Rice Coated with Herbal Extracts: Cooking Quality and Sensory Properties. International Journal of Agricultural and Biosystems Engineering, 9(10), 1119-1124. DOI: doi.org/10.5281/zenodo.1109756.

Yulianto, W.A., Suryani, C.L. and Ulfah, S. (2017). Evaluation of Cooking Quality of Chromium Fortified - Parboiled Rice. IOP Conference Series: Materials Science and Engineering, 193, 012032. https://doi.org/10.1088/1757-899X/193/1/012032

Yulianto, W.A., Susiati, A.M. and Adhini, H.A.N. (2018). Evaluation of resistant starch, glycemic index and fortificants content of premix rice coated with various concentrations and types of edible coating materials. IOP Conf. Series: Earth and Environmental Science, 102, 1-8. https:// doi.org/10.1088/1755-1315/102/1/012101

Zhou, X., Baik, B.K., Wang, R. and Lim, S.T. (2010). Retrogradation of waxy and normal corn starch gels by temperature cycling. Journal of Cereal Science, 51(1), 57-65. https://doi.org/10.1016/ j.jcs.2009.09.005 